\title{
Selection of Poems by David McLoghlin Translated into Spanish
}

\author{
John Liddy (Introduction) \\ Germán Asensio Peral (Translation)
}

Copyright (c) 2017 by David McLoghlin, John Liddy and Germán Asensio Peral. This text may be archived and redistributed both in electronic form and in hard copy, provided that the author and journal are properly cited and no fee is charged for access.

\section{Details into Light}

It has been said of David McLoghlin's first collection Waiting for Saint Brendan (Salmon Poetry, 2012) that "These are big, ambitious, sometimes sprawling poems, rich in narrative and in detail, an autobiography of sorts, where the voyaging soul is concerned to find home and meaning in a dialogue between self and other." It has also been pointed out that McLoghlin "unites sharp 'eye work', in rich and telling detail, with what Rilke called 'heart work', in a series of clear and powerful images". I found the book to be the work of a courageous poet, particularly in section two, where he confronts his own demons as Brendan confronted his.

But the common word in the above commentaries is "detail" and the poems under discussion now are from a forthcoming book, also from Salmon, called Santiago Sketches. For "sketches" we could read "details" because the poems are made from observations in little notebooks kept during a year in Santiago de Compostela and then transferred to bigger pagea-day diaries that the poet bought in those "great Spanish stationery shops".

I remember watching the poet Desmond O'Grady jot down words on torn corners of newspaper pages and carefully fold the tiny pieces of writing and place them in his wallet. Also, I once came across a poem by Heaney on display in the British Library, written on the inside of a Kellogg's cornflakes box. We all have our methods and anything will do really: beer mats, paper serviettes, cigarette boxes, even mobile phones; they all serve the poem, helping it along towards the printed page or to never see the light of day again. Thankfully, we have McLoghlin's perseverance and "eye work" that has given us, in these poems, an outsider's / insider's view of the ordinary, day-to-day happenings in Santiago.

These are not "big, ambitious, sometimes sprawling poems" but rather ethereal, worked-on but not overworked, slightly-controlled reactions to what caught his eye. Instead of photographs, we have photowords. Glimpses, gleanings, scratches and scrapings of life as he experienced it during the course of a year (from 1993 to 94) in that great pilgrim City of Galicia. They are the poet's own searchings on a voyage that would eventually take him to New York.

In a sense, these poems are a pilgrim's store of experiences and longings brought to us by a keen-eyed poet: from "Café Derby" we read of the waiter who could have served Valle Inclán (how we wish for those tertulias again), the bikers in the Obradoiro (this barrio is where the poet mostly hangs out) and the zinc bar counter (not many left now). In "Lamed" we are treated to a wonderful juxtaposition of proud, Napoleonic-type strollers and the medieval clerk wearing a one, four-inch orthopedic shoe and the presence of the Moors - 
never too far from us in Spain. "Map" makes the connection with Ireland and West Clare cheekbones, "Agua De Colonia" "is the smell of Spain" (well, one of them) and "Civil Disagreement" is a snapshot of its political divide. We are back with McLoghlin's penchant for saints in "All Saints" and the day, November 1, tastes of saint's bones (a type of bun), its sound as old fingers rake the dominos (an exact image) and the poet's imaginary escape from the spewing rain to the smells of late summer in Nerja, a thousand kilometers to the south, where the younger McLoghlin used to holiday with his parents.

From here we enter the terrain of people and place and the details that go into making up their lives. In "Pepe's Wife" we can see into her sad apron eyes, the traditional pipers and their flaccid bagpipes like deserters from a forgotten peninsular war, the gong of the poet's silence and the call to prayer (McLoghlin cannot avoid it!). "León with Regina" takes us on an excursion to High Castile and the presence of water where cypress trees grow, a walk past unofficial shebeen bars and the glassed-in balconies are sun traps (they also provide winter warmth). We are back in familiar territory with the seven year wait for a holy door to open as the poet pokes fun at the twelve apostles, while someone else has painted their lips with lipstick. Rain again, as Beckett said, while the priest ignores the beggar and life is a lottery ticket, a street sweeper, a junkie, the poet's dead grandfather in a suburban fir tree in Dublin via Santiago, and the over-grown moss on the cathedral is a beard. Víctor Jara's broken hands are recalled in "Antonio", a poem about a busker, a second chance with Lucía (a girlfriend at the time), Basque rebels and the poet's refusal to play the Irish card. This is followed by "Evening, Quintana" and its café life of dark-haired men, a medieval pilgrim from Dingle (one of the caminos and the place where the poet lived for a few years) writ in stone and gypsies jamming.

"The Book of Beginnings", "First Night" and "Leaving" close the selection included in this issue of Estudios Irlandeses. Each poem is a return to the time when his Santiago experience began. They speak naturally, from hindsight, of sharing cigarettes with old female acquaintances, that Iberian confidence and penchant for profanities that would be shocking in more prudish societies, an epiphany in his old barrio and that predawn walk of loneliness and discovery.

These sketches or searchings are better than any tourist guide. The information is precise, accurate and loyal to people and place. With a little imagination, the reader will relish the detail and if the urge is carried to its conclusion, you could do worse than go to Santiago with these poems in your pocket to guide you. They are the stuff of a poet's pilgrimage, homages to a place that helped him to grow and to complete some of that dialogue with himself and the other. Is not this what the camino is all about. 


\section{CAFÉ DERBY}

Past the leaking umbrella bin of dark wood by the door, girl facing boy, four teenagers play seriously at adulthood. The boys' hair is bullfighter-gelled, deeply engominado; French-style, each girl wears a pastel sweater around her shoulders, another at the waist. They are attended by a small bald waiter who might have served as apprentice at the tertulias of Valle Inclán. Hieratic, a slight limp, the collarless white coat buttoned to the neck, unhurrying he carries a tray to their table - the dark thick hot chocolate from the Americas, the infusiones in alchemical jars, unfurling.

Two biker pilgrims in muddy boots and PLO scarves, stubbled, stand beside elbow-high bikes with Madrid registrationswheel rims choked with mud and dustchatting to a suave traffic cop in the Obradoiro, square of the gold-workers, their bikes parked below the cathedral as if after some Paris-Dakar.

Two elderly women in buffalo fur coats - like the campaign coats of centurionsstand at the zinc counter of the male-dominated bar, talking at each other: small, gesticulating upwards. Old men frown, slapping down dominoes.

\section{LAMED}

Among the proud walkers, each his own Napoleon —only briefly perturbed as a 6 foot 4 blond German passes in rope sandals - go the ones hobble-walking through the drizzle of medieval streets.

And apart from a brief case and beige gabardine, the small man with the four-inch black orthopedic platform shoe could be medieval

- that sense of the afflicted.

Swans asleep in the rain pattering on the art deco Moorish pool

in the Alameda -

the name of the park,

it means grove of poplars.

\section{CAFÉ DERBY}

Al cruzar el oscuro paragüero de madera, chorreando junto a la puerta, chica para chico, cuatro jovenzuelos galantean serios con la madurez. Los chicos y su cabello, fijado a lo torero, intensamente engominado; a la francesa, las chicas revisten sus hombros con jerséis pastel, y a la cintura otro.

Los atiende un camarero, calvo y retaco, de menester quizá madurado desde mozo en las tertulias de Valle Inclán. Hierático, algo renco, viste una blanca chaquetilla sin cuello abotonada hasta la garganta, parsimonioso. Les lleva una bandeja a la mesa-denso, de las américas, caliente chocolate negro, infusiones en ánforas de alquimia, bullendo.

Dos motoristas peregrinos de botas lodosas, con palestinas y barba de tres días, están de pie junto a sus enormes motocicletas, las matrículas de Madridy las llantas bañadas en barro y polvoconversando con un afable policía en el Obradoiro, la plaza de los orfebres, mientras que a los pies de la catedral descansan sus motocicletas, cual persiguiendo un París Dakar.

Dos ancianas, envueltas en abrigos de piel de búfalo - como los que los centuriones vestían en sus campañasse acodan sobre la barra de zinc del varonil bar, conversando entre ellas: gesticulan al cielo, menudas. Los ancianos, ceñudos y en sus dominós, estampan las fichas.

\section{CoJo}

Entre los viandantes orgullosos y napoleónicos - distraídos, quizás, por un alemán, rubio, metro noventa y tresque pasea en sandalias de cáñamo-renquean algunos bajo el sirimiri de callejas medievales.

Maletín y gabardina beige; si no fuera por eso, el pequeño señor del zapato de plataforma, ortopédico, negro, de diez centímetros, parecería del medievo - esa aura de afligido.

Cisnes que dormitan bajo la lluvia y chapotean en la piscina art decó de estilo morisco de la Alamedacuyo nombre significa bosquecillo de álamos. 
MAP

Sky up through the narrow streets.

Old men in berets and suits leaning on sticks talking outside Café das Crechas where copper coins glint between the stones near an Elizabethan map of Ireland.

Dark, bearded young men, cheek wisps above the beard line. Strong, galego-speaking women with Al-Andalus eyes, smoking Ducados. One of them turns: West Clare in her cheekbones. Her hazel eyes, to me, have the intensity of someone young in an old photograph, taken in Quilty a summer day, through a long exposure.

\section{Agua de Colonia}

Under the moped fumes, torrefacto coffee, dark tobacco with no filter, straight aguardiente - throat rip of aniseed, no water no chaserthe public buildings that carry it even in their ammonia - is the smell of Spain: the agua de colonia they put on babies that sells in large bottles for almost nothing. Women cool their wrists with it, dab it behind the pierced ears of baby girls. Gold sleepers.

I've been looking for it since childhood.

The towelettes the Iberia air hostesses passed was that smell. They were beautiful, and tall and I did not understand. It was there in the heat evaporating like jasmine, the haze of gasoline when they opened the door.

\section{CIVIL DISAGREEMENT}

A punky young woman muffled in a PLO scarf, dark-eyed all determined, anarchism and the Basque mullet gets on the bus - an old, blue 1950s city bussays to the driver in galego:

"Praza Roxa, por favor." Red Square.

A man with a long black moustache growls in Castilian:

"Plaza José Antonio Primo de Rivera!"
MAPA

Sube al cielo por las angostas calles.

Ancianos en boina y traje, apoyados en bastones, charlando en la puerta del Café das Crechas, donde monedas de cobre brillan entre las piedras junto a un mapa isabelino de Irlanda.

Mozos morenos y barbudos, con pelillos por encima del contorno de la barba. Mujeres fuertes que hablan gallego con ojos del Al-Andalus, fuman Ducados. Una se gira: el oeste de Clare en sus pómulos. Sus ojos de avellana, para mí, tienen la intensidad de alguien joven en una fotografía antigua, echada en Quilty, un día de verano, con una larga exposición.

\section{AGUA DE COLONIA}

Oculto bajo el humo de las motos, bajo el café torrefacto, bajo el tabaco negro sin filtro, bajo el más puro aguardiente - un anís que desgarra la garganta, sin agua, a palo seco,en muchos edificios públicos está presente, oculto hasta bajo el amoniaco — el olor de España: el agua de colonia con la que embadurnan a los bebés que viene en grandes botellas por cuatro perras. Con él se refrescan las muñecas las mujeres, y lo aplican tras los perforados lóbulos de las niñas. Zarcillos dorados.

Lo busco desde mis años mozos.

De las toallitas de las azafatas de Iberia en los viajes emanaba tal olor. Tan gráciles eran, y tan altas, y yo ni las entendía. Estaba incluso ahí, en ese calor febril, evaporándose como el jazmín, en una bruma de gasoil mientras ellas abrían las puertas.

\section{DESACUERDO CIVIL}

Una punki jovenzuela

de ojos negros, arropada en una palestina, tan suya con su anarquismo y coletilla vasca, se sube al autobús - una cascarria azul de los cincuentay le dice al conductor en galego:

"Praza Roxa, por favor." Plaza Roja.

A lo que un hombre con formidable bigote negro ruge en castellano:

“¡Plaza José Antonio Primo de Rivera!”

\section{TODOS LOS SANTOS}

Hasta los codos de azúcar glas, el pastelero se deleita en decir: "Hoxe comemos osos de Santo!” ¡En el Día de Todos los Santos
Forearms in sugar dust, the baker
relishes saying, " hoxe comemos osos do Santo!" On All Saints Day 
we eat the saint's bones!

Biting down, I get to the sweet marrow of it.

Old men's caps and coats hang on hooks. A cheesy, low-cut variety show on Tele Cinco on mute. Oblivious, stony-faced, they rake the dominoes, rake through bones. At the next table, a card player flicks one down onto once-plush baize, and turns away with the contempt of the defeated.

Under the spout drains in the Old Town

- mouths of monsters spewing rain-

I'm thinking of Nerja

a thousand kilometres to the south.

In November, the air in Andalusia

still holds the deje of summer:

faint bruise - a trace.

I love the way the winter air

has almonds, sea salt

faded jasmine in it,

like breathing nostalgia.

\section{PEPE'S WIFE}

When you go to pay,

she never accepts the money,

motioning you to him with her eyes

- eyes of flies in close-up,

crawling on tapas, eyes of hair

greasy from frying tortilla,

fat, sad apron eyes.

Unshaven gaiteiros in traditional costume, black waistcoats, white shirts, black breeches, flaccid bagpipes over their shoulders, talking among themselves in galego, long bedraggled hair: like deserters who've walked a long way.

White puttee bandages below their knees, black knee-breeches-like the battles drummers from a forgotten peninsular war falling behind among the prostitutes and their children, the stumbling camp followers.

3 a.m.: I walk home mist through the old town.

- Gong!- Gong!

Rim of my silence. nos comemos los huesos del santo!

Bocado a bocado llego

al dulce tuétano.

Las boinas y abrigos de los ancianos penden del perchero.

El show de Telecinco, soso e insulso, en silencio. Abstraídos, pétreos sus rostros, remueven los dominós, rebuscan entre huesos. En la otra mesa, un jugador de cartas estampa una sobre el tapete, antaño terso, y se vuelve con la vehemencia del vencido.

Bajo las bocas de las canaletas en el casco antiguo - fauces de fieras que esputan lluviapienso en Nerja, un millar de kilómetros más abajo.

En Noviembre, en el aire de Andalucía todavía vuela ese deje de verano: una mera muesca - una marca. Adoro el invierno y su viento de almendras, de sal marina, de jazmín vaporoso, una bocanada de nostalgia.

\section{LA MuJer DE PePE}

Cuando toque pagar, nunca aceptará el dinero, y con sus ojos a él te mandará - Ojos de mosca en primer plano, que se arrastran por las tapas, ojos de cabellos aceitosos de freír tortilla, ojos de delantal, orondos, mustios.

Gaiteros sin afeitar en sus trajes regionales, negros el calzón y chaleco, blanca la camisa, sobre sus hombros una gaita flácida, en galego entablan sus conversaciones, pelandreras largas y lardosas: como desertores que han hecho un largo camino. bajo sus rodillas, blancos vendajes sobre calzones cortos negros - como un tamborilero de un conflicto peninsular de antaño, en la retaguardia junto a las prostitutas y sus críos, a trompicones, siguiendo al ejército.

3 de la madrugada: camino a casa

la niebla devora el casco antiguo

- Gong!- Gong!

El filo de mi silencio. 
Loud speakers on the minarets

of the cathedral

as if for some call to prayer.

\section{LEÓN WITH REGINA}

In High Castile,

between cypress trees marking water,

a transhumance of sheep washes across the road from white stubble fields.

- Shepherds in red wool jerseys waving us on.

Walking out of the city along Calle Pombal in the late afternoon, women lean in doorways. They don't call to me, even tiredly. I glimpse empty beer crates in shebeen bars,

bedrooms behind curtains at the back of them.

Glassed-in balconies are sun traps

for women born before the civil war.

White-panelled wood between the panes, grey-blue double doors, green tendrils trailing down the grey iron.

Faint wood-smoke over the old town.

Leaving Thomas' flat into the Rúa do Vilar and then the cathedral - the Puerta Santa's closed, won't open for another seven years. Statues of apostles in relief around the door whisper against each other behind their hands, as if at shift's end.

Someone's painted their lips with lipstick.

One stall left in the Rúa Nova.

A woman walks past under an umbrella,

her Siamese cat peeps

over an upturned collar.

A small priest bent over in his cassock, passes beggars in the rain. I wonder where to go in the Quintana dos Mortos, in the city of time.
Megáfonos en los minaretes

de la catedral

como para llamar a la oración.

\section{LEÓN CON REGINA}

En la Alta Castilla,

entre cipreses que señalan el agua, una trashumancia de ovejas inunda la carretera desde campos de blanco rastrojo.

- Los pastores y sus jerséis rojos de lana nos dan paso.

Cruzando calle Pombal para salir de la ciudad bien entrada la tarde, las mujeres se asoman a los portales. No me saludan, ni con desgana. Atisbo barriles de cerveza vacíos en cuchitriles, cuartos tras cortinas al fondo.

Los balcones acristalados son trampas de sol para las mujeres nacidas antes de la Guerra Civil. Paneles de madera blanca unen los cristales, puertas dobles azules y grises, zarcillos verdes que descienden junto al hierro gris.

El débil humo de las chimeneas cubre el casco antiguo.

Salir del piso de Thomas a la Rúa do Vilar y justo ahí la catedral—-la Puerta Santa está cerrada, y no se abrirá hasta dentro de siete años. Las estatuas de los apóstoles cuidan la puerta, aliviados, cuchichean entre sí con las manos a la espalda, como al acabar sus turnos. Alguien les ha pintado los labios con pintalabios.

Solo queda un puesto en la Rúa Nova.

Una mujer pasa de largo resguardada en un paraguas, y su gato siamés se asoma sobre el cuello de la camisa.

Un cura bajito, doblado

en su sotana, deja atrás a los mendigos bajo la lluvia. Me pregunto a dónde ir en la Quintana dos Mortos, en la ciudad del tiempo. 
No letters today. The ONCE lottery ticket seller in the glass booth with venetian blinds Braille-counting a roll of 5,000 pesetas notes. My lungs' harsh residue.

“¡Vamos, hombre!” an old man says to the rheumatic Alsatian straying behind him as if to a friend.

Three o'clock. White-jacketed waiters in El Paradiso café serve tea to old women in the in-between time.

Two female students link arms under their umbrella.

A street sweeper in navy overalls, luminous white stripes at her ankles and sleeves, a witch's broom sweeping long trajectories.

The junkies shelter under the arches in the Toural square. Old men stand beside the police.

The police ignore them, the old men keep nodding as if they were included.

Smell of astringent pines by the Auditorio. Mist drifting across the houses on the hill like wood smoke. A smell of damp grass, or the perennial berries of suburban fir trees at the end of gardens in Dublin. My dead grandfather.

Long, beard-moss on the cathedral. An aged foreign couple, white-haired, strolling. A cherub flying, all cheek.

Eroded lion faces watch them out of the stone.

\section{ANTONIO}

Most nights there was a busker in the arch under Bishop Xelmirez's palace - the acoustics so good you heard him long before you came up the stairs from the Obradoiro. He sat because of the long hours, and when he stood he walked as if his leg had been turned the wrong way. I didn't know his name.

10 years later, Lucía and I were walking down from Cervantes,
No hay cartas hoy. El vendedor de la ONCE en su cabina de cristal de persianas venecianas cuenta en braille un manojo de billetes de 5000 pesetas. El penetrante residuo de mis pulmones.

“¡Vamos, hombre!" le dice un anciano al reumático y descarriado alsaciano a su espalda, como si fuera un amigo.

Las tres. Camareros de chaquetilla blanca sirven té a ancianas en la cafetería El Paradiso en el intermedio.

Dos chicas estudiantes entrelazan sus brazos bajo el paraguas.

Una barrendera en un mono azul marino, líneas blancas fluorescentes en sus tobillos y mangas, la escoba de una bruja que barre largos trayectos.

Los yonquis se resguardan bajo los arcos de la plaza Toural. Algunos ancianos aguardan junto a los agentes.

Los policías los ignoran, pero los ancianos siguen asintiendo, como si los tuviesen en cuenta.

El astringente aroma de los pinos junto al Auditorio. la niebla que se desliza sobre las casas de la colina como humo de leña. El olor a césped húmedo o las bayas perennes de los abetos al final de los jardines a las afueras de Dublín. Mi abuelo muerto.

*

Musgo largo y barbiespeso en la catedral. Una anciana pareja de extranjeros de níveo pelo, pasea. Un querubín que vuela, todo mejillas. Erosionadas facciones de león que los vigilan desde la piedra.

\section{ANTONIO}

Muchas noches merodeaba un músico bajo el palacio del Obispo Xelmirez, bajo el arco - la acústica tan buena que lo escuchabas mucho antes de pasar el Obradoiro y subir las escaleras. Sentado por la larga jornada, cuando se ponía de pie andaba como con la pierna mal torcida. No sabía su nombre.

10 años más tarde, descendíamos por Cervantes Lucía y yo, 
Santiago starting again for me.

He was playing "Te Recuerdo, Amanda" by Víctor Jara. "¡Claro!” he said to her, "you played at singer-songwriter nights at Modus Vivendi!" At midnight his girlfriend collected him with their Golden Retriever. She was a student, 10 years younger. As they walked away I thought of second chances, and Lucía's student days when she said "every window was open playing Pablo Milanés, Mercedes Sosa, and Silvio," Latin American hope songs. Behind the songs, compañeros, Víctor Jara-and me and her missing each other in every Old Town bar, me missing being in a different book.

Tarasca sometimes played the hope songs, more often rebel songs, flew the Basque Ikurrina beside the Cuban star. When I ordered in Spanish the bearded bartender looked at me askance under black-and-white photos of prisoners, friends of the axe and the asp - echoes of a mural iconography. He turned stony, I wouldn't play the Irish card. Off my elbow, a local wore the balaclava and the armalite, foregrounded on the Tricolour: the easy t-shirt.

Víctor Jara was on the juxebox.

"Try playing that on the guitar," the soldiers mocked in the stadium in Santiago de Chile, after they broke his hands. Víctor Jara sang back at them from the ground.

\section{EVENING, QUINTANA}

A fiddler on the steps-
tertulia in Café Literarios.

The open door casts a yellow path on the flagstones: to warm voices, points closely-argued, dark-haired men standing, laughing

- and then 19th century beards, friends meeting daily at the coffee house mightn't be that far.

I stop to listen,

then go on.

A man runs past, like a fugitive

the cathedral's towers far above him.

Sickle moon, Jewish star.

Tower of contradictory heart.

Old ladies pant, linking arms climbing the hill of Costa Vella. A black cat sits watching almost in schadenfreude. In the Obradoiro
Santiago tocándome la fibra de nuevo.

Él tocaba "Te Recuerdo, Amanda"

de Víctor Jara. “¡Claro!” le dijo a ella,

“¡Tú tocaste en el Modus Vivendi, en las noches de cantautores!

A las doce lo recogía su novia con su Golden Retriever. Era universitaria,

10 años más joven. Y pensé entonces en las segundas oportunidades mientras se marchaban, y en los días

de estudiante de Lucía, cuando decía "todas las ventanas

abiertas al ritmo de Pablo Milanés, Mercedes Sosa y Silvio,"

temas latinoamericanos de esperanza. Y tras la canción,

compañeros, Víctor Jara-y ella y yo

sin encontarnos en ningún bar del casco antiguo,

echando yo de menos estar en otro libro.

En Tarasca ponían a veces los temas de esperanza, o más bien himnos rebeldes, e izaban la Ikurriña vasca a la par de la estrella Cubana. Cuando pedí en castellano, el velludo camarero me miró receloso bajo fotos de prisioneros en blanco y negro, amigos del hacha y la áspid - ecos de una iconografía mural. Se volvió impasible, decidí no sacarme de la manga a Irlanda. Pegado a mi codo, un parroquiano llevaba el pasamontañas y el armalite sobre fondo de la Tricolor: la camiseta inevitable.

Sonaba Víctor Jara en la gramola.

"Intenta tocar eso con la guitarra,"

le dirían los soldados entre risas en el estadio de Santiago de Chile, al partirle la mano. Víctor Jara les cantó desde el suelo.

\section{NOCHE, QUINTANA}

Un violinista en el escalóntertulia en el Café Literarios.

La puerta abierta proyecta una senda amarilla sobre los adoquines: que te lleva a voces cálidas, a argumentos bien defendidos, a hombres morenos de pie, entre risas

—y entonces barbas decimonónicas; encontrarse amigos a diario en las cafeterías no puede quedar tan lejos.

Me paro a escuchar,

y me marcho.

Un hombre pasa corriendo, como un fugitivo,

las torres de la catedral lo vigilan desde lo alto. Luna de hoz, estrella judía.

Torre de corazones contradictorios.

Jadean las ancianas, y unen sus brazos

para subir la cuesta de Costa Vella.

Sentado, un gato negro observa

casi riéndose de los males ajenos.

En el Obradoiro 
the stone is still warm from the sun.

At the five star hotel, a waiter looks out, closes the door, making the quiet comes closer.

To the west, a spectrum of blue-black, red-green, darker red, where the sun is going down.

\section{A faint cross decipherable in sandstone.}

The full moon in a window in whose light sometimes I see writing on the stone: graffiti of an Irish pilgrim. They wrote El Dinguel de Santiago in the book of arrivals, then he missed the boat back.

The gitanos jamming in the Quintana: the boy on the guitar, the older man's voice starts up unsure, shivering-knife.

Two teenaged girls — eyes of India.

How long since you left home?

\section{THE BOOK OF BEGINNINGS}

Women I knew, then, who smoked Ducados would pass me a drag from time to time in the Praza de Mazarelos black tobacco, the gentle laceration - and me trying to find the page.

The old woman wearing her beauty like dried flowers. The Iberian confidence still fresh.

At the Platerías door of the cathedral old men sit, talking.

¡Me cago en dios!- "I shit on God!"- one routinely punctuates.

The arcade arches la piedra aún conserva el calor del sol.

En el hotel de cinco estrellas, se asoma un camarero, cierra la puerta $\mathrm{y}$ hace que se acerque el silencio $\mathrm{Al}$ oeste, un espectro de negroazul, verdirrojo, rojo oscuro, donde el sol se hunde.

La sombra de una cruz discernible en la arenisca.

La luna llena en una ventana, y en su luz a veces veo garabatos en la piedra: el grafiti de un peregrino irlandés. Escribieron El Dinguel de Santiago en el registro de llegadas, $\mathrm{Y}$ entonces perdió el barco de vuelta.

Los gitanos montan jaleo en la Quintana: el niño con su guitarra, y la voz del hombre que arranca vacilante, trémula - cuchillo. En plena adolescencia, dos chicas — ojos de la India.

¿Cuándo la dejasteis atrás?

\section{EL LIBRO DE LOS PRINCIPIOS}

Conocía mujeres, por aquel entonces, que fumaban Ducados y que me dejaban una calada de vez en cuando en la Praza de MazarelosTabaco negro, esa suave flagelación-y yo tratando de encontrar la página.

La anciana

viste su belleza como flores marchitas. Su confianza ibérica aun joven.

Junto a la puerta de las Platerías en la catedral se sientan ancianos, que charlan.

¡Me cago en dios!-

puntualiza uno cada poco.

Los arcos de la galería 
of Rúa Nova and do Vilar

sheltered them in the winter.

Now in late June, perverse,

they walk in the shade.

The cicadas make a deeper silence as summer opens its distances.

\section{FIRST NIGHT}

After Café Derby, a single street led up, up the incline. Now I know it is Preguntoiro: I didn't know it was the old town, didn't know anything. Displays of tetilla - tit cheeseand flesh-tone girdles - but nothing open, the whole city a brownish stone that glittered. Out of narrowness, the Quintana suddenly opened. There was no one-as if the world had retreated, and it was given to me. Rain dripped from the arches, from everything, but there was no rain falling. I stood there a long time as it glistened.

\section{LEAVING}

"Owl singing in the quiet night

in the shadow of mingled boughs,

you turn these city trees

into an old wood where I always was..."

Uxío Noveneyra (Translated by Pearse Hutchinson)

Avenue of trees by Fonseca.

I stand looking at a fountain

at six in the morning

walking home in the cool June dawn,

the breeze-silence with cut-grass in it

or fresh wood smoke:

a first fire, or embers of the last. de Rúa Nova y do Vilar

los resguardaban en invierno.

Hoy, en este Junio tardío,

ellos, perversos, pasean por la sombra.

Las cigarras caen en un silencio más profundo mientras el verano se abre en la distancia.

\section{PRIMERA NOCHE}

Pasando el Café Derby, una sola calle sube y sube la cuesta. Preguntoiro, ahora sí lo sé: no sabía que era el casco antiguo, ignoraba todo. Tetilla en los escaparates - queso de mama y fajas reductoras - pero nada abierto, toda la ciudad una reluciente piedra pardusca. Al principio estrecha, la Quintana se abría de repente. Y luego ni un alma - como si el mundo estuviese de retiro, y me lo hubieran regalado. De los arcos goteaba la lluvia, de todos sitios, pero no del cielo.

Esperé de pie mucho rato mientras brillaba.

\section{MARCHÁNDOME}

\author{
"Moucho que cantas pra noite queda \\ na sombra das flairas tecidas, \\ ti fais distas arbres de cidade \\ un bosque antigo no que eu estuven sempre..." \\ Uxío Noveneyra \\ Un bulevar junto a Fonseca. \\ A observar una fuente me detengo \\ a las seis de la mañana \\ de camino a casa en el fresco amanecer de Junio \\ bajo la sosegada brisa con aroma a césped cortado \\ o a humo de chimenea: \\ el primer fuego, o ascuas del último.
}

\section{Notes}

All the poems between asterisks are individual units, regardless of their having a title or not.

John Liddy was born and educated in Ireland but has lived in Madrid since 1982, where he worked both as a librarian and teacher at the British Council. He has published the following books of poetry: Boundaries (1974), The Angling Cot (1991), Song of the Empty Cage (1997), Wine and Hope (1999), Cast-a-Net (2003), The Well (2007), Gleanings (2010) and The Secret Heart of Things (2014). He is one of the founders of the journal The Stony Thursday Book.

German Asensio Peral obtained his bachelor's degree at the University of Almería (Spain) with an honorary distinction. He earned his Master's Degree in English 
Studies at the University of Almería. He is currently working on his Ph.D. dissertation on Irish writer Flann O'Brien and his journalistic production. His latest publication is "Myles na gCopaleen's Cruiskeen Lawn and the Politics of Revival.” Nordic Irish Studies (2016). 